\title{
Metal bioaccumulation in common carp and rudd from the Topolnitsa reservoir, Bulgaria
}

\author{
Vesela Yancheva $^{1}$, Stela Stoyanova ${ }^{1}$, Iliana Velcheva ${ }^{1}$, Slaveya Petrova ${ }^{1}$, and Elenka Georgieva ${ }^{2}$ \\ Department of Ecology and Environmental Conservation ${ }^{1}$, Department of Developmental Biology ${ }^{2}$, Faculty of Biology, \\ University of Plovdiv, Plovdiv, Bulgaria
}

Received in October 2013

CrossChecked in October 2013

Accepted in February 2014

\begin{abstract}
Concentrations of arsenic $(\mathrm{As})$, cadmium $(\mathrm{Cd})$, copper $(\mathrm{Cu})$, nickel $(\mathrm{Ni})$, lead $(\mathrm{Pb})$, and zinc $(\mathrm{Zn})$ were determined in water samples and five fish organs (gills, liver, kidney, spleen, and muscle) of common carp (Cyprinus carpio L.) and common rudd (Scardinius erythrophthalmus L.) from the Topolnitsa reservoir (Bulgaria) in three seasons (spring, summer, and autumn). This water ecosystem is located in a copper mining and metallurgical region. Water metal concentrations were significantly higher in the summer than in the spring $(p<0.05)$. Moreover, $\mathrm{As}, \mathrm{Cd}, \mathrm{Cu}$, and $\mathrm{Zn}$ concentrations were higher than the national limits. Qualitative factors "element" and "fish organ" had a stronger influence on metal bioaccumulation than the factors "season" and "fish species". In fish, the highest metal levels were detected in the liver, spleen, kidney and gills, and the lowest in the dorsal muscle. Tissue levels were higher in the summer, but in general they were similar between the two Cyprinid fish. Fish muscles had the lowest metal levels at all times, but $\mathrm{As}$ and $\mathrm{Pb}$ exceeded the national and international standards. Therefore, we would not recommend fish consumption from Topolnitsa, as continuous metal contamination of the reservoir may seem to present human health risk.
\end{abstract}

KEY WORDS: bioaccumulation; freshwater fish; ICP-MS; organs

Contamination of aquatic ecosystems with metals has received increasing attention worldwide $(1,2)$. Metal contaminants are of particular concern due to high toxicity, persistence, and ability to accumulate in the food chain and aquatic ecosystems $(3,4)$. Metals enter the aquatic environment through atmospheric deposition and erosion of the geological matrix. Anthropogenic sources include fuel combustion, industrial effluents, wastewater from smelting, metallurgical or mining enterprises, and leaching from waste rocks and mine tailings $(5,6)$. After entering the water, metals may precipitate or adsorb on the surface of solids, remain soluble or suspended in it, or may be taken up by flora and fauna (7).

Fish are a major protein source for humans, fish muscle in particular, and health risks of food poisoning with metals have become a major concern in recent decades (8-10). Fish may also serve as reliable indicators of metal contamination because they are more sensitive to changes in the aquatic environment than invertebrates and tend to accumulate metals in concentrations several times higher than that of the ambient medium $(11,12)$. Fish are exposed to metals through water and food (13). Metal bioaccumulation depends on many factors such as fish species, age, tissue, season, $\mathrm{pH}$, water temperature, and hardness (14). In teleosts, the most common tissues used in toxicology studies are the gills, liver, kidney, and muscles $(15,16)$. Metal levels in gills reflect metal concentrations in the surrounding water; liver is an organ for storage and detoxification of metals, whereas kidney is involved in the process of excretion (17). 
Spleen in fish is a haematopoietic organ with important functions. However, it has not been investigated in bioaccumulation studies as thoroughly as the liver and kidney $(18,19)$.

Topolnitsa (Bulgaria, $42^{\circ} 25^{\prime} 90^{\prime \prime} \mathrm{N} 23^{\circ} 59^{\prime} 38^{\prime \prime}$ E) is a reservoir built on the Topolnitsa River which runs through a region rich with copper mines, mine tailings, and metallurgy plants. In addition, the reservoir serves as a final sink for all types of contaminants which are carried with the river and its tributaries. Even though these circumstances call for a full investigation and monitoring, no data have been published over the last few decades on metal levels and their effects on fish from this artificial lake. Gecheva et al. (20) recently provided information on metal levels in water and sediment samples along the Topolnista River basin. However, their results cannot be used as reference, as we investigate still water and their study a flowing water.

The aim of our study was to address all of the above issues: 1) to establish current water pollution data on As, $\mathrm{Cd}, \mathrm{Cu}, \mathrm{Ni}, \mathrm{Pb}$, and $\mathrm{Zn}$ concentrations of the Topolnitsa reservoir and see if there are seasonal differences; 2) to compare metal bioaccumulation in common carp and common rudd gills, liver, kidney, spleen, and muscle and to see how metal pollution reflects on organs with different structure and functions; and 3) to compare metal levels in the fish muscle with national and international standards for safe consumption.

\section{MATERIALS AND METHODS}

\section{Sampling area}

The Topolnitsa reservoir (Figure 1) is located near the village of Muhovo, south-west Bulgaria $(63 \mathrm{~km}$ from the capital Sofia, $444 \mathrm{~m}$ above the sea level). The reservoir was built in 1961 and is one of the largest artificial lakes in the country with a total volume of 140 million $\mathrm{m}^{3}$ of water. All samples were collected near the dam wall ( $86 \mathrm{~m}$ high, $338 \mathrm{~m}$ long) in the spring, summer, and autumn of 2012.

\section{Water sampling and analysis}

Surface water samples for metal analysis were collected in triplicates in prewashed, double-caped polyethylene bottles following the procedures described by the ISO standard 5667-4 (21). Samples

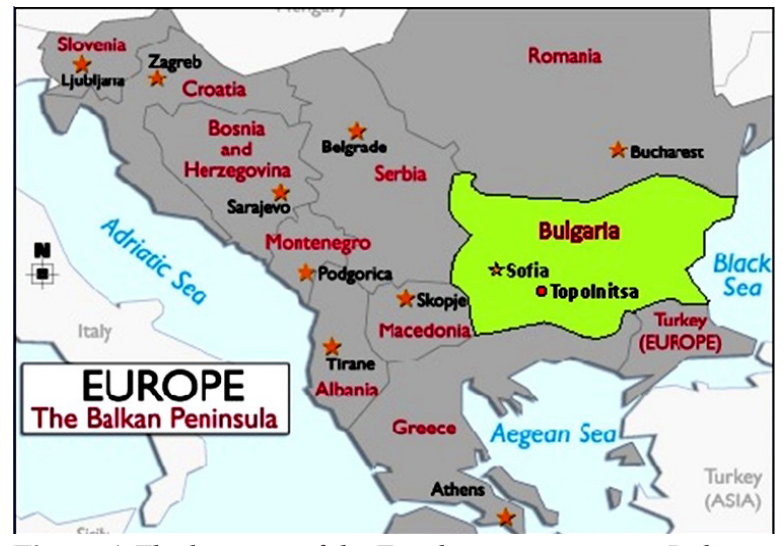

Figure 1 The location of the Topolnitsa reservoir in Bulgaria

were acidified with $1 \% \mathrm{HNO}_{3}$ and stored on ice for as short time as possible to minimise changes in metal physicochemical properties before analysis. We also recorded water $\mathrm{pH}$, temperature $\left({ }^{\circ} \mathrm{C}\right)$, dissolved oxygen, and conductivity $\left(\mu \mathrm{S} \mathrm{cm}^{-1}\right)$.

For reference we used water from the ponds in which the Institute of Fisheries and Aquaculture in Plovdiv rears fish under strict toxicant-free conditions.

Water was analysed for metals according to the ISO standard 17294-2 (22) with an Agilent 7500ce (Agilent Technologies, Tokyo, Japan) inductively coupled plasma mass spectrometer (ICP-MS), and the findings are reported as $\mu \mathrm{g} \mathrm{L}^{-1}$. The detection limit of the instrument was $0.5 \mu \mathrm{g} \mathrm{L}^{-1}$ for As, $0.05 \mu \mathrm{g} \mathrm{L}^{-1}$ for $\mathrm{Cd}, 0.5 \mu \mathrm{g} \mathrm{L}^{-1}$ for $\mathrm{Cu}, 0.5 \mu \mathrm{g} \mathrm{L} \mathrm{L}^{-1}$ for $\mathrm{Ni}, 10 \mu \mathrm{g} \mathrm{L}^{-1}$ for $\mathrm{Pb}$, and $10 \mu \mathrm{g} \mathrm{L}^{-1}$ for $\mathrm{Zn}$.

\section{Fish sampling and analysis}

Common carp (Cyprinus carpio, L.) is spread and farmed all over Bulgaria and Europe and has been used as a test organism in many toxicological assays (23-25) because of its relative resilience even to heavy pollution $(26,27)$. Common rudd (Scardinius erythrophtalamus, L.) is a Cyprinid species of many European rivers and lakes, fished recreationally. Even though metal levels have been reported in common rudd organs, mainly in the gills, liver, and muscle (28, 29), toxicological data on common rudd are quite scarce compared to other Cyprinids.

In parallel with water sampling, ten fish of each species were caught with fishing nets in each season, which totalled 60 fish. All samples were collected following the EMERGE Fish Sampling Manual for Live Fish (30). Prior to dissection, fish length and weight were measured to the nearest millimetre and gram (mean common carp and rudd weight was 
$101.1 \pm 4 \mathrm{~g}$ and $55.2 \pm 13.2 \mathrm{~g}$ and length $15.5 \pm 0.7 \mathrm{~cm}$ and $15.4 \pm 1.2 \mathrm{~cm}$, respectively). Dissection was performed in a provisional field laboratory with clean stainless steel scalpel blades, scissors, and tweezers. We first dissected the second gill arch on the right side and then carefully removed the liver, kidney, and spleen. Finally, we took a small piece of the dorsal muscle. All samples were placed in pre-marked clean polyethylene zip-lock bags and kept on ice until we froze them in our laboratory at $-25^{\circ} \mathrm{C}$ for analysis.

For reference we obtained from the national Institute of Fisheries and Aquaculture in Plovdiv five healthy fish of each species for each of the three seasons, totalling 15 carps (mean weight $120 \pm 1.2 \mathrm{~g}$; mean length $14.9 \pm 1.9 \mathrm{~cm}$ ) and 15 rudds (mean weight $51 \pm 13.2 \mathrm{~g}$; mean length $13 \pm 1.5 \mathrm{~cm}$ ).

All experiments were conducted in accordance with the Directive 2010/63/EU on the protection of animals used for scientific purposes (31).

Metal bioaccumulation was analysed in the gills, liver, kidney, spleen, and dorsal muscle of the two fish species. Approximately $1 \mathrm{~g}$ of each tissue sample was wet mineralised using a microwave digestion system (Milestone Ethos Plus, Italy) at $200{ }^{\circ} \mathrm{C}$. Digestion solution was prepared with $6 \mathrm{~mL}$ of $65 \% \mathrm{HNO}_{3}$ and $2 \mathrm{~mL}$ of $30 \% \mathrm{H}_{2} \mathrm{O}_{2}$. After mineralisation, samples were diluted to $25 \mathrm{~mL}$ by adding ultra-pure water and analysed for metal content using an Agilent 7500ce ICP-MS. Data are reported as $\mu \mathrm{g} \mathrm{kg}^{-1}$ wet weight. The detection limit of the instrument was: $10 \mu \mathrm{g} \mathrm{kg}^{-1}$ for As, $1 \mu \mathrm{g} \mathrm{kg}^{-1}$ for $\mathrm{Cd}, 10 \mu \mathrm{g} \mathrm{kg}^{-1}$ for $\mathrm{Cu}, 10 \mu \mathrm{g} \mathrm{kg}^{-1}$ for $\mathrm{Ni}, 30 \mu \mathrm{g} \mathrm{kg}^{-1}$ for $\mathrm{Pb}$, and $30 \mu \mathrm{g} \mathrm{kg}^{-1}$ for $\mathrm{Zn}$.

All analyses were carried out at the regional laboratory of the Executive Environment Agency in Plovdiv, Bulgaria. Reagents were purchased from the Merck Group (Darmstadt, Germany) and were of analytical and Suprapur ${ }^{\circledR}$ quality. Glassware was washed with non-ionic detergent, treated with a solution of $10 \% \mathrm{HNO}_{3}$ for $48 \mathrm{~h}$, and rinsed thoroughly with deionised water before use to minimise contamination.

\section{Method validation}

Analysis included samples in triplicates and batches with blanks. Accuracy was validated using standard reference materials for trace elements in water SRM 1643e (National Institute of Standards and Technology, Gaithersburg, MD, USA) and fish protein DORM-3 (National Research Council Canada, Ottawa, ON, Canada). All results showed a good agreement with the standards, and recovery ranged between $96 \%$ and $105 \%$ for fish and $92 \%$ and $101 \%$ for water.

\section{Statistical analysis}

Raw data on metal concentrations in water and fish samples were distributed normally and analysed using STATISTICA version 7.0 for Windows (StatSoft Inc., New York, NY, USA). Differences between the variables were tested for significance using Student's $t$-test $(p<0.05)$. Relationships between metal concentrations in water and in fish tissues were tested using Pearson's product-moment correlation, principal components analysis (PCA) $(p<0.05)$. Data are reported as mean $\pm \mathrm{SD}$.

\section{RESULTS AND DISCUSSION}

\section{Metal concentrations in water}

Table 1 shows general Topolnitsa water quality parameters, which meet the Basin Directorate for Water Management - East Aegean Region (Bulgaria) requirements for healthy aquatic environment for fish (unpublished data).

Table 2 shows metal concentrations in water samples taken from Topolnitsa. In reference water all

Table 1 Topolnitsa reservoir water quality parameters

\begin{tabular}{lcccc} 
Season & $\mathbf{p H}$ & $\mathbf{T}\left({ }^{\circ} \mathbf{C}\right)$ & $\begin{array}{c}\text { Conductivity } \\
\left(\boldsymbol{\mu} \mathbf{S ~ c m}^{-1}\right)\end{array}$ & $\begin{array}{c}\text { Dissolved oxygen } \\
\left(\mathbf{m g ~ L}^{-1}\right)\end{array}$ \\
\hline Spring & 8.3 & 5.1 & 330 & 8.3 \\
Summer & 8 & 19.4 & 620 & 7 \\
Autumn & 6.1 & 4.2 & 410 & 9 \\
\hline Mean \pm SD & $8.1 \pm 0.2$ & $9.6 \pm 8.5$ & $453.3 \pm 150$ & $8.1 \pm 1$ \\
\hline
\end{tabular}


Table 2 Metal concentrations (mean $\pm S D$ ) in the Topolnitsa reservoir water ( $n=3$ in each season)

\begin{tabular}{lcccc}
\hline \multirow{2}{*}{ Element } & \multicolumn{4}{c}{ Metal concentrations $\left(\boldsymbol{\mu g} \mathbf{L}^{-1}\right)$} \\
\cline { 2 - 5 } & Spring & Summer & Autumn & Bulgarian limits \\
\hline $\mathrm{As}$ & $\mathbf{2 0 0 \pm 1 0 ^ { * }}$ & $4 \pm 0.1^{*}$ & $10 \pm 1^{*}$ & 10 \\
$\mathrm{Cd}$ & $\mathbf{0 . 6} \pm \mathbf{0 . 1}$ & $0.4 \pm 0.1$ & $-*$ & 0.5 \\
$\mathrm{Cu}$ & $\mathbf{2 0} \pm \mathbf{1}$ & $\mathbf{2 0} \pm \mathbf{1}$ & $\mathbf{1 0} \pm \mathbf{5}$ & 1 \\
$\mathrm{Ni}$ & $3 \pm 1$ & - & - & 20 \\
$\mathrm{~Pb}$ & - & - & - & 7 \\
$\mathrm{Zn}$ & $8 \pm 0.001^{* *}$ & $\mathbf{2 0 0} \pm \mathbf{0 . 0 1 * *}$ & $*$ & 8
\end{tabular}

below the detection limit: $0.5 \mu g L^{-1}$ for As, $0.05 \mu g L^{-1}$ for $C d, 0.5 \mu g L^{-1}$ for $C u, 0.5 \mu g L^{-1}$ for $N i, 10 \mu g L^{-1}$ for Pb, and $10 \mu g L^{-1}$ for $\mathrm{Zn}$

*significantly different between the seasons $(\mathrm{p}<0.05)$

Bold-above the Bulgarian limit

metal concentrations were below the detection limit of the instrument. Lead concentrations in the Topolnitsa water also kept below the detection limit in all three seasons, whereas other metal concentrations varied significantly between the spring and summer $(p<0.05)$. Cadmium concentrations dropped below the detection limit in the autumn, $\mathrm{Ni}$ concentrations in the summer and autumn, and $\mathrm{Zn}$ concentrations in the autumn. In contrast, $\mathrm{As}$ and $\mathrm{Cu}$ were measurable in all three seasons, which may indicate chronic exposure of the biota to these toxicants. Spring As and Cd, and summer $\mathrm{Zn}$ concentrations exceeded the maximum permissible values set by the Bulgarian regulations (32, 33) based on the Directive 2000/60/EC (34). Autumn As and spring $\mathrm{Zn}$ concentrations were borderline. Furthermore, $\mathrm{Cu}$ concentrations were above the permissible levels in all three seasons, probably due to intensive copper mining in the region. However, concentrations of the other metals are more likely related to background levels and complex interactions between water, sediment, and biota, or may be caused by anthropogenic factors other than mining (domestic sewage, industrial waste waters and agricultural runoff).

\section{Metal bioaccumulation in fish}

We wanted to see which of the selected qualitative factors, namely "element", "fish organ", and "season" had stronger influence on metal bioaccumulation in either of the Cyprinid fish. Our PCA analysis (Figures 2 and 3) determined that "element" had more influence (common carp - $71.73 \%$; common rudd $-64.05 \%$ ) than "season" (common carp - $20.23 \%$; common

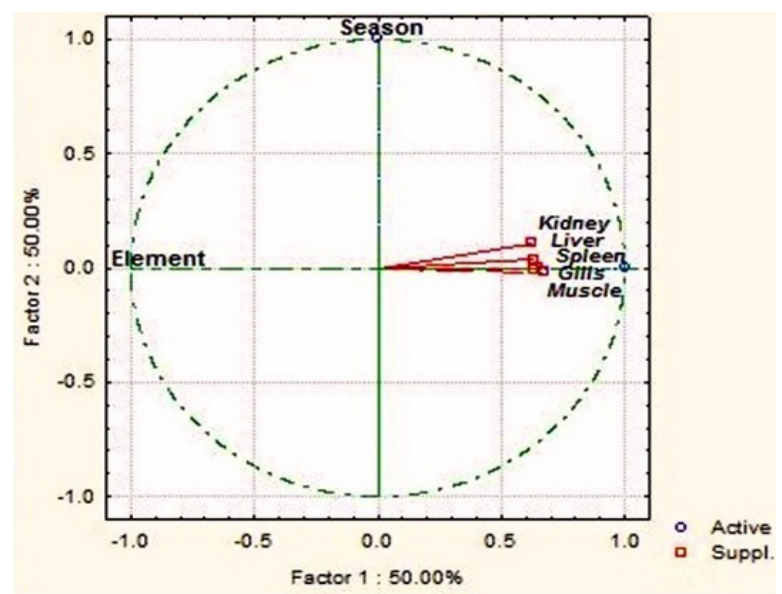

Figure 2 Relationship between qualitative factors "element" and "season" for common carp: axis $x$ represents the significance of the factor "element" (71.73\%); axis $y$ represents the significance of the factor "season" (20.23\%)

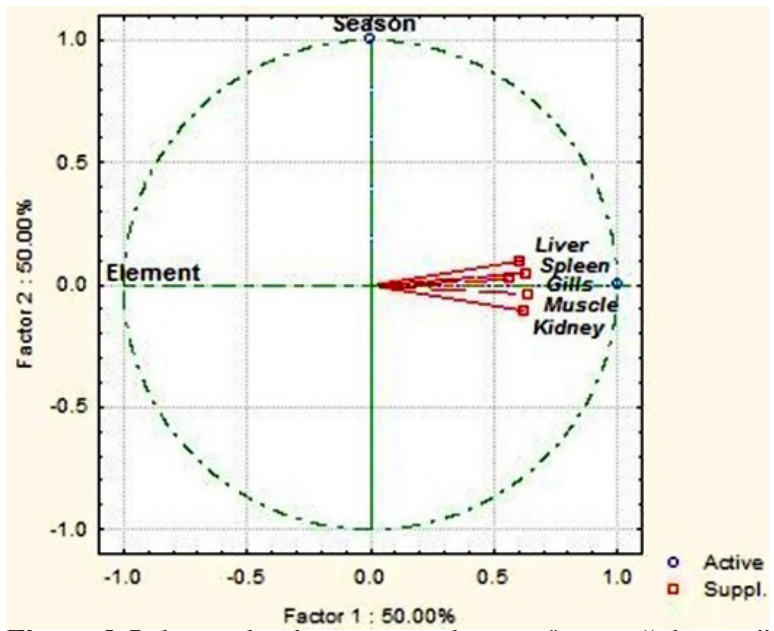

Figure 3 Relationship between qualitative factors "element" and "season" for common rudd: axis $x$ represents the significance of the factor "element" (64.05\%); axis $y$ represents the significance of the factor "season" (18.09\%) 
rudd $-18.09 \%$ ), which suggests that metal properties and bioavailability in the aquatic environment are important for metal bioaccumulation.

Qualitative factor "fish organ" also proved important for metal bioaccumulation (Figure 4), as the studied organs differed in their affinity to metals. Internal organs (liver, kidney, and spleen) showed the highest affinity, followed by the gills and muscles. Qualitative factor "season" had less influence on metal bioaccumulation.

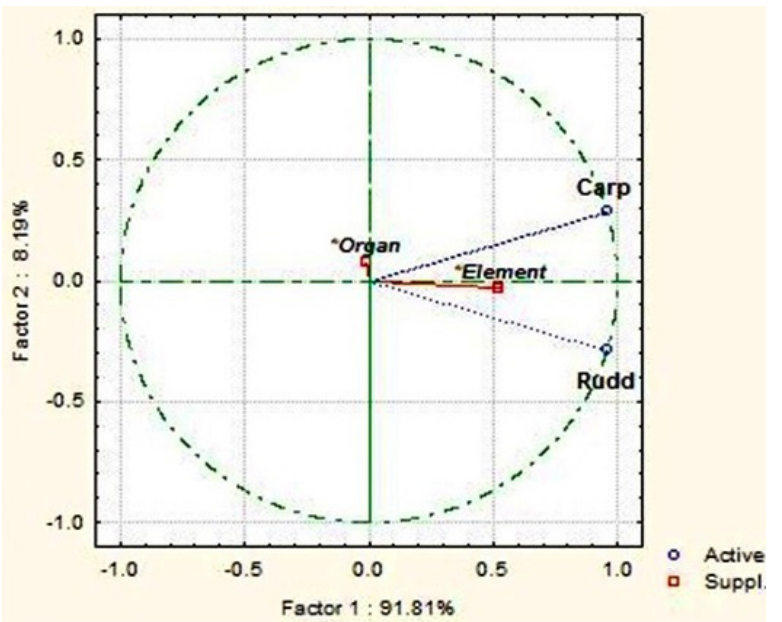

Figure 4 Relationship between qualitative factors "element" and "organ" for common carp and common rudd: axis $x$ represents the significance of the factor "element" (64.05\%), axis y represents the significance of the factor "organ" $(8.09 \%)$

Metal mass fractions in the organs of common carp and common rudd from Topolnitsa were higher than the reservoir water concentrations (Table 3 ), whereas all reference fish metal levels were below the detection limit of the instrument. The highest metal mass fractions in both fish species were measured in the summer, even though not all seasonal differences were significant.

Gills are considered an important point of entry into the organism for essential $(\mathrm{Cu}, \mathrm{Zn}, \mathrm{Se}, \mathrm{Mn}, \mathrm{Fe})$ and non-essential elements (Al, As, $\mathrm{Cd}, \mathrm{Cr}, \mathrm{Pb})(35)$ and are a useful tool for assessing metal bioavailability and accumulation in water (17). We found a positive correlation between water and spring gill As concentrations irrespective of the fish species $(\mathrm{r}=0.84$ for carp and $\mathrm{r}=0.63$ for rudd), as both had similar metal concentrations. The same is true for the summer gill $\mathrm{Zn}$ concentrations ( $\mathrm{r}=0.72$ for carp and $\mathrm{r}=0.64$ for rudd). Even though statistics did not establish significant correlations between other gill metal levels and water metal levels, we believe that the correlations established for As and Zn sufficiently support that the
Cyprinid fish gills can accurately reflect water metal contamination. We share the opinion of Teien et al. (36), Hansen et al. (37), and Terra et al. (38), who think that the reason for this is that the gills, being negatively charged, bind positively charged metal species in the water. Our results confirm other reports that fish gills reflect lower water quality (39-41).

Once metals cross the biological barrier and enter the bloodstream, they will reach and accumulate in the internal organs of fish, which explains the significantly higher internal organ metal levels in our study. Another reason for higher metal levels in the internal organs may be gastrointestinal route of exposure (13), rendering the liver and the kidney additionally vulnerable to chronic metal exposure (42). Similar to Falfushynska and Stoliar (43) and Siscar et al. (44), we think that metal accumulation in internal organs is associated not only with organ function such as haematopoiesis, antioxidant defence, detoxification, and excretion, but also with metallothionein synthesis. Our results are also in agreement with those of Shinn et al. (45) and Poleksić et al. (46), who measured the highest metal levels in the internal organs. All metal variations in our study may be related to changes in the abiotic factors and fish metabolic activity or to individual fish susceptibility and features in the biology of common carp and common rudd. We also agree with Sokolova and Lannig (47) that toxicant bioaccumulation increases with water temperature, as it accelerates the crossing of metals over biological barriers, which may account for seasonal variations. The positive correlation we found between water and carp liver $\mathrm{Cu}(\mathrm{r}=0.80)$ and water and rudd liver $\mathrm{Cu}$ $(\mathrm{r}=0.72)$ in all three seasons as well as between water and carp kidney $\mathrm{Cd}(\mathrm{r}=0.65)$ support the leading role these organs have for metal storage.

The spleen also showed high metal levels in both fish species. $\mathrm{Cd}$ and $\mathrm{Cu}$ in common rudd spleen significantly varied between some of the seasons and were significantly higher than carp findings (Table 3 ). Summer $\mathrm{Pb}$ and $\mathrm{Zn}$ in common carp spleen were significantly higher than in the spring and autumn. In addition, our results suggest that $\mathrm{Zn}$ has strong affinity for this organ ( $r=0.72$ for carp; $r=0.63$ for rudd) and that the spleen is as important depot for metals as the liver and kidney. It carries important functions such as new lymphocyte formation, breakdown of old red blood cells, and overall immune response. We therefore think that toxicology studies should stop underestimating this organ and use it more often to assess transfer and distribution of metals in fish, as 
Table 3 Metal mass fractions (mean $\pm S D$ ) in common carp and common rudd organs from the Topolnitsa reservoir (ten samples per fish species per season)

\begin{tabular}{|c|c|c|c|c|c|c|c|c|}
\hline \multirow{2}{*}{ 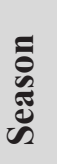 } & \multirow{2}{*}{$\stackrel{a}{\cong}$} & \multirow[b]{2}{*}{ Organ } & \multicolumn{6}{|c|}{ Element $\left(\mu \mathrm{g} \mathrm{kg} \mathbf{~}^{-1}\right)$} \\
\hline & & & As & Cd & $\mathrm{Cu}$ & $\mathbf{N i}$ & $\mathbf{P b}$ & $\mathbf{Z n}$ \\
\hline \multirow{10}{*}{ 告 } & \multirow{5}{*}{ ฮై } & gills & $60 \pm 10 *$ & $700 \pm 30$ & $900 \pm 50$ & $300 \pm 10$ & $400 \pm 10^{\S}$ & $126000 \pm 1000$ \\
\hline & & liver & $900 \pm 10$ & $900 * \pm 50$ & $16000 * \pm 300$ & $1700 \pm 50 *$ & $2400 \pm 300$ & $109000 \pm 100$ \\
\hline & & kidney & $1200 \pm 300$ & $200 \pm 10^{*}, \S$ & $1600 \pm 300^{\S}$ & $1100 \pm 50^{*}$ & $1000 \pm 500^{*}$ & $134000 \pm 500$ \\
\hline & & spleen & $1100 \pm 300$ & $100 \pm 10^{\S}$ & $2000 \pm 500$ & $1500 \pm 50 *$ & $1700 \pm 500^{*}$ & $397000 \pm 300$ \\
\hline & & muscles & $70 \pm 10$ & $1 \pm 0.5$ & $500 \pm 30^{\uparrow}$ & $400 \pm 10$ & $300 \pm 10^{\uparrow}$ & $8000 \pm 500$ \\
\hline & \multirow{5}{*}{$\begin{array}{l}\text { 을 } \\
\text { 르 }\end{array}$} & gills & $100 \pm 10$ & $100 \pm 10$ & $1300 \pm 200$ & $100 \pm 10$ & $11000 \pm 300^{\S}$ & $40000 \pm 500$ \\
\hline & & liver & $1300 \pm 500$ & $1300 \pm 10^{\S}$ & $8000 \pm 500^{\S}$ & $1400 \pm 10$ & $1300 \pm 300^{\S}$ & $170000 \pm 500$ \\
\hline & & kidney & $1140 \pm 500$ & $2100 \pm 300 * \S$ & $4000 \pm 300$ & $1100 \pm 10$ & $2300 \pm 500$ & $290000 \pm 3500$ \\
\hline & & spleen & $1200 \pm 30$ & $500 \pm 10$ & $1500 * \pm 10$ & $1500 \pm 10$ & $2000 \pm 20$ & $198000 \pm 500^{\S}$ \\
\hline & & muscles & $100 \pm 10^{\uparrow}$ & $10 \pm 1$ & $300 \pm 10$ & $40 \pm 10$ & $60 \pm 10$ & $7000 \pm 500$ \\
\hline \multirow{10}{*}{ 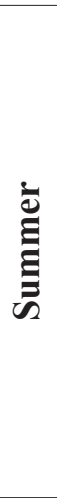 } & \multirow{5}{*}{ ٍั้ } & gills & $90 \pm 20$ & $700 \pm 30$ & $2800 \pm 300$ & $300 \pm 1$ & $300 \pm 10^{\S}$ & $152000 \pm 730$ \\
\hline & & liver & $1300 \pm 10$ & $8800 \pm 500 *, \S$ & $53000 \pm 200 * \S$ & $5500 \pm 300 *$, & $5500 \pm 500^{\S}$ & $174000 \pm 500$ \\
\hline & & kidney & $1600 \pm 400$ & $2000 \pm 50^{*}, \S$ & $3000 \pm 500$ & $3300 \pm 500 *$, & $3300 \pm 100 *$ & $313000 \pm 1500$ \\
\hline & & spleen & $1900 \pm 500$ & $200 \pm 10$ & $2000 \pm 500$ & $3900 \pm 500 *$, & $3900 \pm 300^{*}$ & $654000 \pm 550^{*}, \S$ \\
\hline & & muscles & $60 \pm 1$ & $30 \pm 10$ & $300 \pm 10$ & $200 \pm 10$ & $200 \pm 10^{\uparrow}$ & $8200 \pm 300$ \\
\hline & \multirow{5}{*}{ 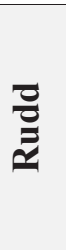 } & gills & $100 \pm 10$ & $300 \pm 0.01$ & $1800 \pm 200$ & $200 \pm 10$ & $1200 \pm 50$ & $50000 \pm 200$ \\
\hline & & liver & $2000 \pm 700$ & $1600 \pm 0.05^{\S}$ & $17000 \pm 1000^{\S}$ & $1500 \pm 10$ & $1300 \pm 10^{\S}$ & $56000 \pm 500$ \\
\hline & & kidney & $2000 \pm 500$ & $5500 \pm 0.2^{*}$ & $6000 \pm 500^{\S}$ & $1400 \pm 500^{\S}$ & $2100 \pm 500$ & $283500 \pm 1000$ \\
\hline & & spleen & $1400 \pm 300$ & $800 \pm 0.01^{\S}$ & $5000 \pm 500 *$, & $1500 \pm 300$ & $2100 \pm 100$ & $46000 \pm 1500^{\S}$ \\
\hline & & muscles & $100 \pm 1^{\uparrow}$ & $20 \pm 0.001$ & $300 \pm 10$ & $100 \pm 3$ & $30 \pm 1$ & $8000 \pm 300$ \\
\hline \multirow{10}{*}{$\stackrel{\Xi}{E}$} & \multirow{5}{*}{ نे } & gills & $700 \pm 30 *$ & $200 \pm 10$ & $1900 \pm 400$ & $400 \pm 10$ & $500 \pm 1$ & $124000 \pm 250$ \\
\hline & & liver & $900 \pm 50$ & $1300 \pm 50 *, \S$ & $19000 \pm 2000 * \S$ & $2500 \pm 300$ & $2500 \pm 100$ & $134000 \pm 2500$ \\
\hline & & kidney & $1000 \pm 200$ & $800 \pm 50 * \S$ & $1300 \pm 50$ & $1900 \pm 500$ & $2000 \pm 100$ & $287000 \pm 2500$ \\
\hline & & spleen & $1300 \pm 500$ & $150 \pm 30$ & $1500 \pm 300^{\S}$ & $2200 \pm 200$ & $1900 \pm 500^{*}$ & $385000 \pm 5^{*}$ \\
\hline & & muscles & $70 \pm 2$ & $40 \pm 1$ & $260 \pm 40$ & $150 \pm 10$ & $150 \pm 30$ & $7800 \pm 300$ \\
\hline & \multirow{5}{*}{ 를 } & gills & $100 \pm 10$ & $100 \pm 1$ & $2000 \pm 500$ & $200 \pm 10$ & $800 \pm 10$ & $50000 \pm 500$ \\
\hline & & liver & $1300 \pm 500$ & $1100 \pm 1^{\S}$ & $16000 \pm 1500^{\S}$ & $2000 \pm 10$ & $1600 \pm 300$ & $263000 \pm 500$ \\
\hline & & kidney & $1140 \pm 500$ & $3000 \pm 500^{\S}$ & $3000 \pm 500$ & $1200 \pm 10^{\S}$ & $2400 \pm 400$ & $243000 \pm 300$ \\
\hline & & spleen & $1200 \pm 300$ & $100 \pm 1^{\S}$ & $2000 \pm 500$ & $1400 \pm 10$ & $2700 \pm 500$ & $272000 \pm 300^{\S}$ \\
\hline & & muscles & $100 \pm 10^{\uparrow}$ & $10 \pm 1$ & $200 \pm 50$ & $15 \pm 1$ & $20 \pm 1$ & $5600 \pm 100$ \\
\hline
\end{tabular}

high metal levels in this organ can point to oxidative stress, morphological alterations, or biochemical disturbances.

Dorsal muscles of both species had the lowest metal concentrations, and our findings are in agreement with earlier reports $(48,49)$. It is well known that the muscle does not actively accumulate metals and seems to have a very fast decontamination rate. The increasing concern about the health risks of food poisoning (50) due to consumption of fish meat contaminated with metals has prompted Bulgaria to adopt several standards and recommendations (5153) into national legislation (Table 4). However, there are huge differences between the maximum permissible metal levels in fish meat set by the Bulgarian regulations and the Joint FAO/WHO standards (53). In addition, the European Commission has omitted $\mathrm{As}, \mathrm{Cu}, \mathrm{Ni}$, and $\mathrm{Zn}$ from its regulations, and the $\mathrm{FAO} /$ WHO have omitted $\mathrm{Cd}, \mathrm{Ni}$, and $\mathrm{Zn}$. This calls for crucial changes in environmental legislation. 
Table 4 National and international standards and guidelines on maximum permissible metal concentrations (mass fractions) in fish meat.

\begin{tabular}{lcccccc}
\hline \multirow{2}{*}{ Regulation/Guideline } & \multicolumn{7}{c}{ Limit concentration $\left(\boldsymbol{\mu g} \mathbf{~ k g}^{-1}\right)$} \\
\cline { 2 - 7 } & As & Cd & Cu & Ni & Pb & Zn \\
\hline Bulgarian regulation (2004) & 1000 & 50 & 10000 & 50 & 200 & 50000 \\
EC Regulation (2006) & - & 50 & - & - & 300 & - \\
FAO/WHO (2014) & 100 & - & 400 & - & 300 & - \\
\hline
\end{tabular}

Therefore, even though our measurements show borderline or excessive levels only for $\mathrm{Pb}$ in carp and As in rudd dorsal muscle, we would not recommend Topolnitsa fish consumption, having in mind the toxicity and the ability of these metals to bioaccumulate in the food web. Moreover, Topolnitsa has constantly been contaminated with a cocktail of metals since the early 1960s, and the anthropogenic pressure has not faltered. We therefore propose regular monitoring that would involve metal analysis in both the abiotic and biotic compartments (fish muscles).

\section{Acknowledgements}

We would like to thank the experts from the regional laboratory of the Executive Environment Agency of Bulgaria for helping with metal analyses. We would also like to thank the manuscript editor and anonymous peer reviewers for their contributions to this manuscript.

\section{REFERENCES}

1. Sekabira K, Oryem Origa H, Basamba TA, Mutumba, G, Kakudidi E. Assessment of heavy metal pollution in the urban stream sediments and its tributaries. Int J Environ Sci Technol 2010;7:435-46. doi: 10.1007/BF03326153

2. Carrasco L, Benejam L, Benito J, Bayona JM, Díez S. Methylmercury levels and bioaccumulation in the aquatic food web of a highly mercury-contaminated reservoir. Environ Int 2011;37:1213-8. doi: 10.1016/j. envint.2011.05.004

3. Kumar B, Sajwan KS, Mukherjee DP. Distribution of heavy metals in valuable coastal fishes from North East coast of India. Turk J Fish Aquat Sci 2012;12:81-8. doi: 10.4194/13032712-v12 110

4. Zeng J, Yang L, Wanga X, Wang WX, Wu QL. Metal accumulation in fish from different zones of a large, shallow freshwater lake. Ecotoxicol Environ Saf 2012;86:116-24. doi: 10.1016/j.ecoenv.2012.09.00

5. Moiseenko TI. The fate of metals in Arctic surface waters Method for defining critical levels. Sci Total Environ 1999;236:19-39. doi: 10.1016/S0048-9697(99)00280-6
6. Fu F, Wang Q. Removal of hevy metal ions from wastewaters: a review. J Environ Manage 2011;92:407-18. doi: 10.1016/ j.jenvman.2010.11.011

7. Palaniappan PL, Karthikeyan S. Bioaccumulation and depuration of chromium in the selected organs and whole body tissues of freshwater fish Cirrhinus mrigala individually and in binary solutions with nickel. J Environ Sci (China) 2009;21:229-36. doi: 10.1016/S1001-0472(08)62256-1

8. Yi Y, Yang Z, Zhang S. Ecological risk assessment of heavy metals in sediment and human health risk assessment of heavy metals in fishes in the middle and lower reaches of the Yangtze River basin. Environ Pollut 2011;159:2575-85. doi: 10.1016/j.envpol.2011.06.011

9. Fallah AA, Saei-Dehkordi SS, Nematollahi A, Jafari T. Comparative study of heavy metal and trace element accumulation in edible tissues of farmed and wild rainbow trout (Oncorhynchus mykiss) using ICP-OES technique. Microchem J 2011;98:275-9. doi: 10.1016/j. microc.2011.02.007

10. Özparlak H, Arslan G,Arslan E. Determination of some metal levels in muscle tissue of nine fish species from Beyşehir Lake, Turkey. Turk J Fish Aquat Sci 2012;12:761-70. doi: 10.4194/1303-2712-v12 404

11. Has-Schön E, Bogut I, Strelec I. Heavy metal profile in five fish species included in human diet, domiciled in the end flow of river Neretva (Croatia). Arch Environ Contam Toxicol 2006;50:545-51. doi: 10.1007/s00244-005-0047-2

12. Velcheva I. Zinc content in the organs and tissues on freshwater fish from the Kardjali and Studen Kladenets Dam Lakes in Bulgaria. Turk J Zool 2006;30:1-7.

13. Sloman KA. Effects of trace metals on salmonid fish: The role of social hierarchies. Appl Anim Behav Sci 2007;104:32645. doi: 10.1016/j.applanim.2006.09.003

14. Ural M, Yildirim N, Danabas D, Kaplan O, Cikcikoglu Yildirim N, Ozcelik M, Kurekci EF. Some heavy metals accumulation in tissues in Capoeta umbla (Heckel, 1843) from Uzuncayir Dam Lake (Tunceli, Turkey). Bull Environ Contam Toxicol 2012;88:172-6. doi: 10.1007/s00128-0110474-x

15. Velcheva I. Content and transfer of Cadmium $(\mathrm{Cd})$ in the organs of fresh water fish. Acta Zool Bul 2002;54:109-14.

16. Uysal K, Emre Y, Köse E. The determination of heavy metal accumulation ratios in muscle, skin and gills of some migratory fish species by inductively coupled plasma-optical emission spectrometry (ICP OES) in Beymelek Lagoon (Antalya/Turkey). Microchem J 2008;90:67-70. doi: 10.1016/j.microc.2008.03.005

17. Heier LS, Lien IB, Ljønes M, Rosseland BO, Salbu B, Strømseng AE, Tollefsen KE. Speciation of lead, copper, zinc and antimony in water draining a shooting range - time 
dependant metal accumulation and biomarker responses in brown trout (Salmo trutta L.). Sci Total Environ 2009;407:4047-55. doi: 10.1016/j.scitotenv.2009.03.002

18. Čelechovska O, Svobodova ŽV, Macharaekova B. Distribution of metals in tissues of the common carp (Cyprinus carpio L.). Acta Vet Brno 2007;76:93-100. doi: 10.2754/avb200776S8S093

19. Beltcheva M, Metcheva R, Peneva V, Marinova M, Yankov Y, Chikova V. Heavy metals in Antarctic notothenioid fish from South Bay, Livingston Island, South Shetlands (Antarctica). Biol Trace Elem Res 2011;141:150-8. doi: 10.1007/s12011-010-8739-5

20. Gecheva G, Yurukova L, Mattia C, Cheshmedjiev S. Monitoring of aquatic mosses and sediments: a case study in contaminated rivers, Bulgaria. Plant Byosystems Published online: 12 Nov 2013 doi: 10.1080/11263504.2013.857736

21. ISO 5667-4: 1987. Water quality - Sampling - Part 4: Sampling Guidance on sampling from lakes, natural and man-made.

22. ISO 17294-2: 2003. Water Quality. Application of Inductively Coupled Plasma Mass Spectrometry (ICP-MS) - Part 2: Determination of 62 Elements.

23. Brumbaugh WG, Schmitt CJ, May TW. Concentrations of cadmium, lead, and zinc in fish from mining-influenced waters of northeastern Oklahoma: sampling of blood, carcass, and liver for aquatic biomonitoring. Arch Environ Contam Toxicol 2005;49:76-88. doi: 10.1007/s00244-004-0172-3

24. De Boeck G, Van der Ven K, Meeus W, Blust R. Sublethal copper exposure induces respiratory stress in common and gibel carp but not in rainbow trout. Comp Biochem Phys C Toxicol Pharmacol 2007;144:380-90. doi: 10.1016/j. cbpc.2006.11.008

25. Papoutsoglou SE, Miliou H, Karakatsoul NP, Tzitzinakis M, Chadio S. Growth and physiological changes in scaled carp and blue tilapia under behavioral stress in mono and polyculture rearing using a recirculated water system. Aquacult Int 2011;9:509-18. doi: 10.1023/A:1020506814609

26. Snyder EM, Snyder SA, Kelly KL, Gross TS, Villeneuve DL, Fitzgerald SD, Villalobos SA, Giesy JP. Reproductive responses of common carp (Cyprinus carpio) exposed in cages to influent of the Las Vegas Wash in Lake Mead, Nevada, from late winter to early spring. Environ Sci Technol 2004;38:6385-95. doi: 10.1021/es049690n

27. Reynders H, Bervoets L, Gelders M, De Coen WM, Blust R. Accumulation and effects of metals in caged carp and resident roach along a metal pollution gradient in Flanders, Belgium. Sci Total Environ 2008;391:82-95. doi: 10.1016/j. scitotenv.2007.10.056

28. Dušek L, Svobodová Z, Janoušková D, Vykusová B, Jarkovský J, Šmíd R, Pavliš P. Bioaccumulation of mercury in muscle tissue of fish in the Elbe River (Czech Republic): multispecies monitoring study 1991-1996. Ecotoxicol Environ Saf 2005;61:256-67. doi: 10.1016/j. ecoenv.2004.11.007

29. Djedjibegovic J, Larssen T, Skrbo A, Marjanović A, Sober M. Contents of cadmium, copper, mercury and lead in fish from the Neretva river (Bosnia and Herzegovina) determined by inductively coupled plasma mass spectrometry (ICP-MS) Food Chem 2012;131:469-76. doi: 10.1016/j. foodchem.2011.09.009
30. Rosseland BO, Massabuau JC, Grimalt J, Hofer R, Lackner R, Raddum G, Rognerud, S, Vives I. Fish Ecotoxicology: European Mountain Lake Ecosystems Regionalisation, DiaGnostic and Socio-economic Evaluation (EMERGE). Fish Sampling Manual for Live Fish. Oslo: Norwegian Institute for Water Research (NIVA); 2003.

31. Directive 2010/63/EC of the European Parliament and of the Council on the protection of animals used for scientific purposes [displayed 10 February 2014]. Available at http:// eur-1ex.europa.eu/LexUriServ/LexUriServ. do?uri=OJ:L:2010:276:0033:0079:en:PDF

32. Наредба за стандарти за качество на околната среда за приоритетни вещества и някои други замърсители 2010 [Regulation nom of the piority sbstances in srface wters, in Bulgarian]. Available at http://www3.moew.government.bg/ files/file/Legislation/Naredbi/vodi/N_standarti_priorit_ve6t_ zamyrsiteli.pdf

33. НАРЕДБА № Н-4 за характеризиране на повърхностните води 2013 [Regulation norm - H4 of the quality and characterization of surface waters, in Bulgarian]. Available at http://www3.moew.government.bg/files/file/Water/ Legislation/Naredbi/Naredba_H4_za_harakterizirane_na povyrhnostnite_vodi.pdf

34. Directive 2000/60/EC of the European Parliament and of the Council establishing a framework for the Community action in the field of water policy [displayed 10 February 2014]. Available at http://eur-lex.europa.eu/LexUriServ/ LexUriServ.do?uri=OJ:L:2000:327:0001:0072:en:PDF

35. Subotić S, Spasić S, Višnjić-Jeftić Z, AHegediš A, KrpoĆetković J, Mićković B, Stefan Skorić S, Lenhardt M. Heavy metal and trace element bioaccumulation in target tissues of four edible fish species from the Danube River (Serbia). Ecotoxicol Environ Saf 2013;98:196-202. doi: 10.1016/j. ecoenv.2013.08.020

36. Teien H-C, Kroglund F, Salbu B, Rosseland BO. Gill reactivity of aluminium-species following liming. Sci Total Environ 2006;358:206-20. doi: 10.1016/j. scitotenv.2005.04.023

37. Hansen BH, Garmo OA, Olsvik PA, Anderson RA. Gill metal binding and stress gene transcription in brown trout (Salmo trutta) exposed to metal environments: the effect of preexposure in natural populations. Environ Toxicol Chem 2007;26:944-53. doi: 10.1897/06-380R.1

38. Terra BF, Araújo FG, Calza CF, Lopes RT, Teixeira TP. Heavy metal in tissues of three fish species from different trophic levels in a tropical Brazilian River. Water Air Soil Pollut 2008;187:275-84. doi: 10.1007/s11270-007-9515-9

39. Moiseenko TI, Gashkina NA, Sharova YuN, Kudryavtseva LP. Ecotoxicological assessment of water quality and ecosystem health: A case study of the Volga River. Ecotoxicol Environ Saf 2008;71:837-50. doi: 10.1016/j. ecoenv.2008.02.025

40. Monteiro SM, Rocha E, Mancera JM, Fontaínhas-Fernandes A, Sousa M. A stereological study of copper toxicity in gills of Oreochromis niloticus. Ecotoxicol Environ Saf 2009;72:213-23. doi: 10.1016/j.ecoenv.2008.02.008.

41. Wauer G, Teien HC. Risk of acute toxicity for fish during aluminium application to hardwater lakes. Sci Total Environ 2010;408:4020-5. doi: 10.1016/j.scitotenv.2010.05.033

42. Olsvik P, Gundersen P, Andersen R, Zachariassen K. Metal accumulation and metallothionein in two populations of brown trout, Salmo trutta, exposed to different natural water 
environment during a run-off episode. Aquat Toxicol 2000;50:301-16. doi: 10.1016/S0166-445X(00)00094-1

43. Falfushynska HI, Stoliar OB. Function of metallothioneins in carp Cyprinus carpio from two field sites in Western Ukraine. Ecotoxicol Environ Saf 2009;72:1425-32. doi: 10.1016/j.ecoenv.2009.02.013

44. Siscar R, Koeni S, Torreblanca A, Solé M. The role of metallothionein and selenium in metal detoxification in the liver of deep-sea fish from the NW Mediterranean Sea. Sci Total Environ 2013;466-467:898-905. doi: 10.1016/j. scitotenv.2013.07.081

45. Shinn C, Dauba F, Grenouillet G, Guenard G, Lek S. Temporal variation of heavy metal contamination in fish of the river lot in southern France. Ecotoxicol Environ Saf 2009;72:1957-65. doi: 0.1016/j.ecoenv.2009.06.007

46. Poleksić V, Lenhardt M, Jarić I, Đorđević D, Gačić Z, Cvijanović G, Rašković B. Liver, gills, and skin histopathology and heavy metal content of the Danube starlet (Acipenser ruthenus Linnaeus, 1758). Environ Toxicol Chem 2010;29:515-21. doi: 10.1002/etc.82

47. Sokolova IM, Lannig G. Interactive effects of metal pollution and temperature on metabolism in aquatic ectotherms: implications of global climate change. Clim Res 2008;37:181201. doi: $10.3354 / \mathrm{cr} 00764$

48. Vieira C, Morais S, Ramos S, Delerue-Matos C, Oliveira MBPP. Mercury, cadmium, lead and arsenic levels in three pelagic fish species from the Atlantic Ocean: Intra- and interspecific variability and human health risks for consumption.
Food Chem Toxicol 2011;49:923-932. doi: 10.1016/j. fct.2010.12.016

49. Taweel A, Shuhaimi-Othman M,Ahmad AK. Assessment of heavy metals in tilapia fish (Oreochromis niloticus) from the Langat River and Engineering Lake in Bangi, Malaysia, and evaluation of the health risk from tilapia consumption. Ecotoxicol Environ Saf 2013;93:45-51. doi: 10.1016/j. ecoenv.2013.03.031

50. Guérin T, Chekri R, Vastel C, Sirot V,Volatier J-L, Leblanc $J-C$, Noël L. Determination of 20 trace elements in fish and other seafood from the French market. Food Chem 2010;127:934-42. doi: 10.1016/j.foodchem.2011.01.061

51. Наредба № 31 от 29 юли 2004 г. за максимално допустимите количества замърсители в храните [Regulation Norm No 31 from 29 July 2004 setting maximum levels for certain contaminants in foodstuffs, in Bulgarian]. Availabe at http://old.mi.government.bg/norm/nar. html?id=123542

52. Commission Regulation (EC) No 1881/2006 of 19 December 2006 setting maximum levels for certain contaminants in foodstuffs [displayed 10 February 2014]. Available at http:// eur-lex.europa.eu/LexUriServ/LexUriServ. do? uri=CONSLEG:2006R1881:20121203:EN:PDF

53. Joint FAO/WHO food standards programme codex committee on contaminants in foods, Fifth Session [displayed 10 February 2014]. Available at ftp://ftp.fao.org/codex/ meetings/CCCF/cccf5/cf05_INF.pdf 


\section{Sažetak}

\section{Akumulacija metala u šarana i crvenperki iz umjetnog jezera Topolnitsa u Bugarskoj}

Izmjerena je koncentracija arsena (As), kadmija $(\mathrm{Cd})$, bakra $(\mathrm{Cu})$, nikla $(\mathrm{Ni})$, olova $(\mathrm{Pb})$ i cinka $(\mathrm{Zn}) \mathrm{u}$ uzorcima vode te škrgama, jetrima, bubregu, slezeni i leđnom mišiću šarana (Cyprinus carpio L.) i crvenperke (Scardinius erythrophthalmus L.) iz umjetnog jezera Topolnitsa (Bugarska) tijekom tri godišnja doba (proljeće, ljeto i jesen) 2012. Taj se ekosustav nalazi u regiji poznatoj po rudnicima bakra i metalurgiji. Koncentracija metala u vodi bila je značajno viša u ljeto nego u proljeće $(p<0.05)$, a koncentracija As, $\mathrm{Cd}$, $\mathrm{Cu}$ i Zn prelazila je razinu dopuštenu državnim odredbama. Kvalitativni čimbenici "element" i "riblji organ" jače su utjecali na akumulaciju metala od čimbenika "godišnje doba" i "riblja vrsta". Najviša razina metala u riba izmjerena je u jetrima, slezeni, bubregu i škrgama, a najniža u leđnom mišiću. Razina u tkivima bila je malo viša u ljeto, ali se uglavnom nije razlikovala između ribljih vrsta. Mišićna je razina cijelo vrijeme bila niska, ali su zato As i Pb bili iznad domaćih i međunarodnih normi. Stoga ne preporučujemo konzumaciju ribe iz Topolnitse s obzirom na to da stalno zagađenje umjetnog jezera za sobom povlači zdravstvene rizike.

KLJUČNE RIJEČI: bioakumulacija; ICP-MS; slatkovodna riba; unutrašnji organi

\section{CORRESPONDING AUTHOR:}

Vesela Yancheva

University of Plovdiv 'Paisii Hilendarski' Faculty of Biology Department of Ecology and Environmental Conservation P.O. Box 4000, Plovdiv, Bulgaria

E-mail: veselayancheva@yahoo.com 